\title{
PRODUCTION OF PEAR TREES GRAFTED UNDER HYDROPONIC CONDITIONS PRODUÇÃO DE MUDAS PEREIRA ENXERTADAS SOB CONDIÇÕES HIDROPÔNICAS
}

\author{
Aline das Graças de SOUZA ${ }^{(1)}$ \\ Nilton Nagib Jorge CHALFUN ${ }^{(2)}$ \\ Valdemar FAQUIN(3) \\ Ademária Aparecida de SOUZA ${ }^{(4)}$
}

\begin{abstract}
The objective this work was to evaluate the growth and development of Taiwan Naschi-C (Pyrus calleryana Decne) pear rootstocks and scions cultivated hydroponically. The design of the first experiment was in randomized blocks with three replicates involving 75 rootstocks grown from germinated seedlings maintained under hydroponic conditions. The experimental design used in the second experiment was a completely randomized, in a $3 \times 3$ factorial arrangement (three cultivars - 'Triunfo', 'Tenra' and 'Cascatense' and three grafting methods - patch budding, inverted T budding and full cleft grafting), and three times of evaluation, with four replications. Scions of pear cultivars were grafted under hydroponic conditions to prepared rootstocks. Of the 225 rootstocks, $62 \%$ reached transplanting stage $(15 \mathrm{~cm}$ height) at 37 days after transfer (DAT) to hydroponic conditions and $60 \%$ attained grafting stage (4-6 mm diameter stem) at 77 DAT. Full cleft grafting was more efficient and grafts suitable for commercialization were obtained 35 days after grafting (DAG). 'Triunfo' was the most suitable scion, since at 42 DAG the shoot growth of grafts was superior to that obtained with other cultivars. The hydroponics is a viable technique for the propagation of pear plants.

Key-words: Pyrus calleryana; grafting techniques; propagation; Taiwan Naschi-C
\end{abstract}

\section{RESUMO}

O objetivo do trabalho foi avaliar o crescimento e o desenvolvimento dos porta-enxertos Taiwan Nashi-C (Pyrus calleryana Decne) e das mudas de pêra nele enxertado sob condições hidropônicas. No primeiro experimento o delineamento utilizado foi blocos ao acaso, com três repetições de 75 plantas cada no total de 225 tubetes. No segundo experimento, o delineamento utilizado foi inteiramente casualizado, em esquema fatorial $3 \times 3$ (três cultivares - Triunfo, Tenra e Cascatense) e três métodos de enxertia (borbulhia em placa, borbulhia em ' $T$ ' invertido e garfagem de fenda cheia), e três épocas de avaliação, com quatro repetições. De 225 porta-enxertos, $62 \%$ alcançaram o ponto de repicagem (15 cm de altura) aos 37 dias após a transferência (DAT) para condições hidropônicas e $60 \%$ alcançaram o ponto de enxertia (diâmetro de 4-6 cm) aos 77 DAT. A enxertia de garfagem foi a mais apropriada à propagação de mudas de pereira, estando às mesmas prontas para comercialização aos 35 dias após a enxertia (DAE). A cultivar Triunfo apresentou maior crescimento aos 42 DAE. O sistema hidropônico é uma técnica viável para a propagação de pereiras.

Palavras-chave: Pyrus calleryana; enxertia garfagem; propagação.

\footnotetext{
${ }^{(1)}$ Doutoranda em Fitotecnia do Departamento de Agricultura da Universidade Federal de Lavras, Campus Universitário, CEP 37200-000Lavras-MG, Brazil. E-mail: alinedasgracas@yahoo.com.br

(2)Professor Titular do Departamento de Agricultura da Universidade Federal de Lavras, Campus Universitário, CEP 37200-000- Lavras-MG, Brazil. E-mail: nchalfun@ufla.br.

${ }^{(3)}$ Professor Titular do Departamento de Ciência do Solo da Universidade Federal de Lavras, Campus Universitário, CEP 37200-000- LavrasMG, Brazil. E-mail: vafaquin@ufla.br,

(4) Doutoranda em Estatística e Experimentação Agropecuária do Departamento de Ciências Exatas da Universidade Federal de Lavras, Campus Universitário, CEP 37200-000- Lavras-MG, Brazil. E-mail: ademariasouza@yahoo.com.br.
} 
SOUZA, A.G. et al. Production of pears trees...

\section{INTRODUCTION}

The total production of pears (Pyrus communis and $P$. serotina) in Brazil is about of $20,000 \mathrm{t}$ per year whille the total annual consumption (equivalent to $1.2 \mathrm{~kg}$ per person) is 10 fold greater (Nora e Sugiura, 2001).

Out of the temperate climate fruit-bearing trees, the pear tree is the crop which possesses the weakest expression of production and cultivated area in Brazil, among the factors limiting to the expansion of the crop are: the lack of knowledge about management practices and technology deficiency (Simonetto e Grellmann, 1999; Leite et al., 2008).

In order to increase local production, and hence reduce importation, it is essential not only increase the cultivation area but also invest in new technologies, such as more efficient propagation (Reis et al., 2000). In this context the study carried out by Barbosa et al. (1998), in which plants suitable planting were obtained 450 days after the emergence of shoots, illustrates the prolonged duration of the traditional process of pear propagation. In contrast, hydroponics is an efficient method of propagation that has been successfully applied to multiply woody and ornamental species, leafy vegetables, pre-basic potato seed potatoes and fruits such as strawberry and passion fruit (Fagan et al., 2006; Genúncio et al., 2006; Mendes, 2007; Costa \& Leal, 2008).

The objective of this study was to evaluate the growth and development under hydroponic conditions of Taiwan Naschi-C (Pyrus calleryana Decne) rootstocks, and to determine the influence of different grafting methods, employing different scions, on the development of pear grafts on the rootstocks so-obtained.

\section{MATERIAL AND METHODS}

Two trials were carried out, at the Hydroponics Unit of the Soil Science Department of the Federal University of Lavras (Lavras, MG, Brazil; $21^{\circ} 13^{\prime} 55^{\prime \prime}$ S, 445' $43^{\prime \prime}$ W, $925 \mathrm{~m}$ altitude). According to the Köppen criteria, the climate in the region is classified as Cwb, described as temperate/ mesothermal presenting dry winters and the warmest month average temperature below $22{ }^{\circ} \mathrm{C}$, with at least four months averaging above $10^{\circ} \mathrm{C}$.

The first experiment was performed between December 2007 and March 2008 and aimed to evaluate the growth and development of Taiwan Naschi-C rootstocks under hydroponic conditions. The second one was performed between March and May 2008 with the objective to evaluate different grafting techniques and employing scions from different pear cultivars on rootstock obtained at first phase.

The Taiwan Naschi- $C$ rootstocks originated from plant matrices grown at Campinas Agronomic Institute (Campinas, SP, Brazil). Following a period of stratification and germination, 225 pre-germinated seeds were selected and cultivated in plastic tubes (20 $\mathrm{cm}$ high, $5 \mathrm{~cm}$ diameter) filled with vermiculite. The tubes were placed in appropriate supports and maintained in the green house with a daily supply of tap water until the emergence of shoots. Tubes with $2 \mathrm{~cm}$ high seedlings were transferred to shallow hydroponic tanks located inside the green house. The tanks received the nutritive solution (Faquin e Chalfun, 2008) contained in a $1,000 \mathrm{dm}^{3}$ reservoir, pumped to the hydroponic units at 15 min intervals and subsequently returned to the reservoir by gravity through special conduits. The bottom portion of each tube remained immersed in a $5 \mathrm{~cm}$ film of nutrient solution during the entire period of the experiment, thus ensuring a constant supply of nutrients to the seedlings. The $\mathrm{pH}$ of the nutrient solution was maintained between 5.5 and 6.5. The concentrations of macro and micronutrients were adjusted daily according to the measurement of the electrical conductivity $1.62 \mathrm{mg} \mathrm{dm}^{-3}$. The nutrient solution was replaced completely every 30 days.

The experimental design was a randomized block with three replications of 75 seedlings, which were prepared with a single plantlet per tube in a total of 225 tubes. The experiment lasted for 12 weeks. The parameters assessed were related to the time required for the majority of plantlets (60 to $75 \%$ of the total number) to reach a height of $15 \mathrm{~cm}$ (transplanting stage) and a stem diameter of 4-6 mm (grafting stage). Thus, every seven days the height of each plantlet was measured from the crown to the apex with the aid of a ruler $(\mathrm{cm})$, and the diameter of each stem $(\mathrm{mm})$ was measured at a position $15 \mathrm{~cm}$ from the crown with a pachymeter.

The second experiment started when 60 to $75 \%$ of the Taiwan Naschi-C rootstocks had reached the grafting stage, with stem diameter of 4$6 \mathrm{~cm}$. Grafting was performed at a distance of $15 \mathrm{~cm}$ from the crown of the rootstock using scions derived from three different pear cultivars, conditions prevalent in Minas Gerais, period of morning and the root tape. Three methods of grafting were employed: patch budding, inverted $\mathrm{T}$ budding and full cleft grafting. Each grafted rootstock was maintained under hydroponic conditions as described above until the graft attained a size acceptable for a commercial seedling as defined by Ministry of Agriculture and Supply, Ministerial directive number 37-annex-IX (Brazil, 2006).

The experimental design was completely randomized in a $3 \times 3$ factorial arrangement (three cultivars and three grafting methods), in plots and three times of evaluation in sub-plots, with four replications. Each replicate comprised four plants, with a single plantlet per tube, in a total of 144 plantlets. The parameters assessed were the percentage of sprouted scion at 20 days after grafting (DAG), and the height of the shoots measured at 28 DAG and every seven days thereafter. The data were submitted to analysis of variance ( $F$ test) and the mean values relating to the 
factor time, and to the factor type of scion and grafting technique were compared by Tukey test at $5 \%$ of probability level. Values relating to the percentage $(x)$ of sprouting grafts were arc sin transformed $(x / 100)^{0,5}$ prior to statistical analysis. Statistical analyses were conducted with the aid of SISVAR software (Ferreira 2000).

\section{RESULTS AND DISCUSSION}

Seventy per cent of seed-originated rootstocks exhibited excellent vegetative growth under hydroponic conditions (Figure 1). Plantlets attained a mean height of $45.16 \mathrm{~cm}$ and a mean stem diameter of $4.90 \mathrm{~mm} 77$ days after transfer (DAT) to hydroponic conditions. Moreover, $62 \%$ of all plantlets reached the transplantation stage (height of $15 \mathrm{~cm}$ ) within 37 DAT and $60 \%$ attained grafting stage (stem diameter of 4-6 mm) 77 DAT. These results demonstrate that the development of rootstocks is more rapid under hydroponics in

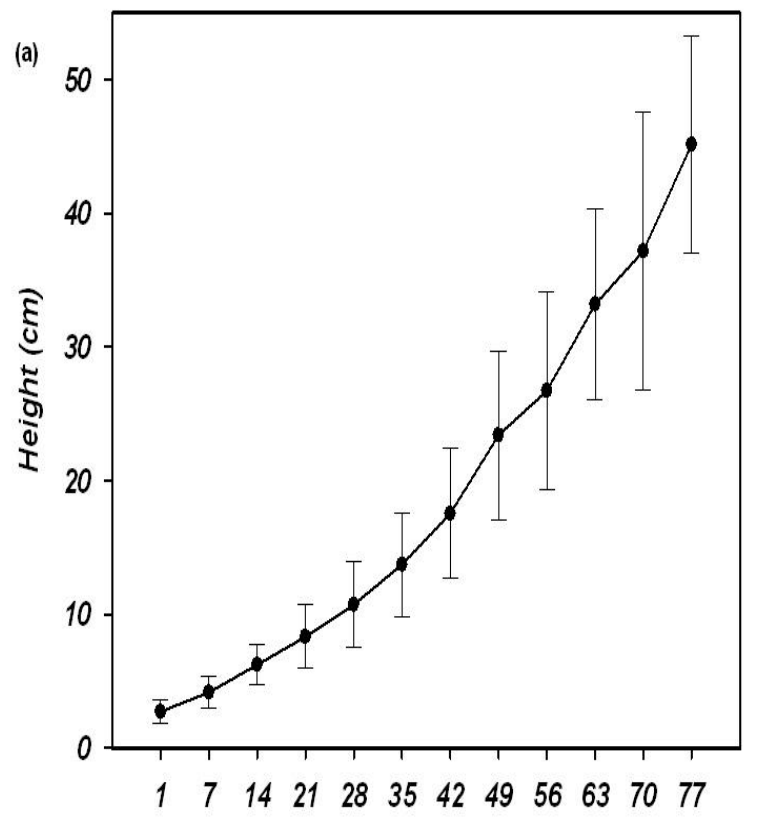

Days after transfer (DAT) to hydroponic conditions comparison with the conventional conditions employed by growers. Barbosa et al. (1997) reported that $65 \%$ of Taiwan Naschi-C pear rootstocks grown at the regular method under netting were suitable for grafting after 240 days. It may be concluded, therefore, that grafting stage could be attained 163 days earlier using a hydroponic technique. However, approximately $30 \%$ of the Taiwan Naschi-C rootstocks grown under hydroponic conditions presented abnormal genetic traits (shrub- and dwarf-like appearance) that would be unsuitable for the future normal development of vigorously growing grafts. In the case of rootstocks grown under netting, only $20 \%$ exhibited such inappropriate characteristics (Barbosa et al., 1997). Moreover, according to Barbosa et al. (1996), there is considerable variability in the rate of vegetative growth of individual rootstocks originated from the same population of seed, whilst genetic heterogeneity is frequently found in populations of fruit trees (Masseron, 1989).

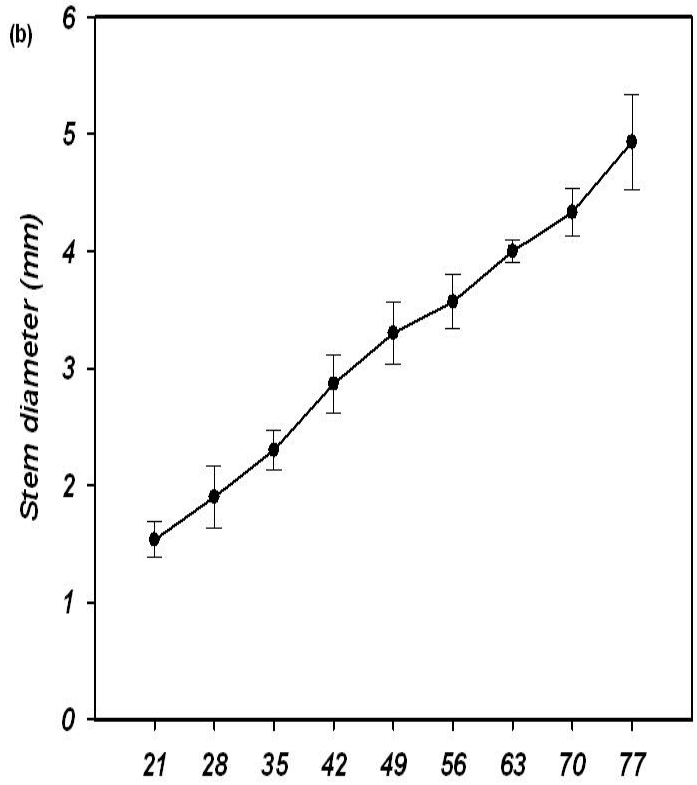

Days after transfer (DAT) to hydroponic conditions

FIGURE 1 Mean and standard deviation of heights (a) and stem diameters (b) of Taiwan Naschi-C plantlets following transfer of pre-germinated seeds to hydroponic conditions.

The percentage of sprouted scions (green shoots) at 20 DAG was influenced $(p<0.05)$ by the grafting technique but not by the scion variety (Table1). There were no significant interactions between the two variables (grafting technique and source of scion). Full cleft grafting produced a significantly $(p<0.05)$ larger percentage of sprouting grafts within the population in comparison with rootstocks submitted to patch budding or inverted $T$ budding. There is evidence in the literature that cleft grafting generally produces a higher percentage of sprouted grafts in comparison with other techniques. Holanda Neto et al. (1996) reported that cleft grafting was the most appropriated propagation method for caju (Anacardium occidentale) trees and Ledo \& Fortes (1991) recommended cleft grafting for graviola (Annona muricata) trees. On the other hand, Mendes (2007) reported that the use of patch budding, inverted $\mathrm{T}$ budding and cleft grafting gave similar percentages of sprouted grafts when peach (Prunus persica) was grafted under hydroponic conditions. 
SOUZA, A.G. et al. Production of pears trees...

TABLE1. Percentage of sprouting grafts assessed 20 days of grafting $^{(1)}$.

\begin{tabular}{|c|c|}
\hline Cultivar & Percentage of sprouting grafts \\
\hline Triunfo & $85 a$ \\
\hline Tenra & $83 a$ \\
\hline Cascatense & $79 a$ \\
\hline \multicolumn{2}{|l|}{ Grafting technique } \\
\hline Patch budding & $75 b$ \\
\hline Normal T budding & $75 b$ \\
\hline Cleft grafting & $98 a$ \\
\hline CV (\%) & 26.52 \\
\hline \multicolumn{2}{|c|}{${ }^{(1)}$ Means followed by the same letters do not differ significantly by Tukey test at $5 \%$ of Probability, DMS=18.36. } \\
\hline $\begin{array}{l}\text { There is evidence in the literature that cleft } \\
\text { grafting generally produces a higher percentage of } \\
\text { sprouted grafts in comparison with other techniques. } \\
\text { Holanda Neto et al. (1996) reported that cleft graft- } \\
\text { ing was the most appropriated propagation method } \\
\text { for caju (Anacardium occidentale) trees and Ledo e } \\
\text { Fortes (1991) recommended cleft grafting for } \\
\text { graviola (Annona muricata) trees. On the other } \\
\text { hand, Mendes (2007) reported that the use of patch } \\
\text { budding, inverted T budding and cleft grafting gave } \\
\text { similar percentages of sprouted grafts when peach } \\
\text { (Prunus persica) was grafted under hydroponic con- } \\
\text { ditions. } \\
\text { In the present study, the height of shoots } \\
\text { produced by grafts was significantly ( } p<0.01 \text { ) influ- } \\
\text { enced by the interaction between grafting technique } \\
\text { and time. Full cleft grafting produced considerably } \\
\text { larger shoots compared with patch budding and } \\
\text { inverted T budding (Table 2), and reached an aver- }\end{array}$ & $\begin{array}{l}\text { size of the rootstocks ( } 15 \mathrm{~cm} \text { in height), such grafts } \\
\text { presented the minimum dimensions required for } \\
\text { commercialisation according to the regulations es- } \\
\text { tablished by the Ministry of Agriculture and Supply, } \\
\text { Ministerial Directive number } 37 \text {-annex-IX (Brazil, } \\
2006 \text { ). On this basis, pear grafts were considered } \\
\text { suitable for field cultivation at } 35 \text { DAG. These results } \\
\text { differ from those obtained by Barbosa et al. (1996) } \\
\text { following grafting experiments with Taiwan Naschi C } \\
\text { rootstocks prepared under netting in a conventional } \\
\text { manner. In this case, grafts could only be trans- } \\
\text { ferred to the field at } 120 \text { DAG, i.e. } 85 \text { days later than } \\
\text { similar grafts cultured under hydroponic conditions. } \\
\text { In this context, Barbosa et al. (1995) had earlier } \\
\text { reported that the time needed for pear plants to } \\
\text { reach field cultivation stage was } 450 \text { days after the } \\
\text { emergence of shoots, i.e. } 338 \text { days longer than hy- } \\
\text { droponically grown plantlets described in this the } \\
\text { present work. }\end{array}$ \\
\hline
\end{tabular}
age height of $35 \mathrm{~cm}$ at 112 DAT. Considering the

TABLE2. Mean heights of pear grafts grown under hydroponic conditions plotted as a function of the number of days after grafting (DAG). Three different scions derived from Cascatense, Triunfo and Tenra cultivars, and three different grafting techniques, namely, inverted T budding, patch budding and cleft grafting ${ }^{(1)}$.

\begin{tabular}{ccccc}
\hline \multirow{2}{*}{$\begin{array}{c}\text { Days after grafting } \\
\text { (DAG) }\end{array}$} & $\begin{array}{c}\text { Days after transfer to } \\
\text { hydroponic (DAT) }\end{array}$ & Triunfo & Tenra & Cascatense \\
\cline { 3 - 5 } 28 & 114 & $13.52 \mathrm{aB}$ & $15.62 \mathrm{aB}$ & $9.87 \mathrm{bB}$ \\
35 & 121 & $19.69 \mathrm{aB}$ & $20.14 \mathrm{aB}$ & $12.85 \mathrm{bB}$ \\
42 & 128 & $31.88 \mathrm{aA}$ & $28.89 \mathrm{bA}$ & $19.54 \mathrm{cA}$ \\
\hline & & & Grafting technique & \\
\cline { 3 - 5 } & & Cleft grafting & Patch budding & Normal T budding \\
\hline 28 & 114 & $28.60 \mathrm{aB}$ & $5.94 \mathrm{bB}$ & $4.48 \mathrm{bB}$ \\
42 & 121 & $34.81 \mathrm{aB}$ & $9.74 \mathrm{bB}$ & $8.13 \mathrm{bB}$ \\
CV $_{1}(\%)$ & 128 & $46.62 \mathrm{aA}$ & $18.17 \mathrm{bA}$ & $15.52 \mathrm{cA}$ \\
\hline
\end{tabular}


The mean height of the shoots produced by grafts was significantly $(p<0.01)$ influenced by the interaction type of scion and time (Table 2). At 28 and 35 DAG (105 and 112 DAT, respectively) the mean heights of grafts prepared using Triunfo and Tenra cultivars were greater than those produced by the Cascatense cultivar, and at 42 DAG (119 DAT) the mean height of the Triunfo grafts $(31 \mathrm{~cm})$ exceeded those of all other cultivars and were appropriate for commercialisation in accordance with the regulations established by the Ministry of Agriculture and Supply, Ministerial directive number 37-annexIX (Brasil, 2006).

It is found in Table 2 that the greatest height in the pear seedlings for the different cultivars and grafting methods was obtained in the latest time evaluated (128 DAT).

In the second experiment, all pear grafts were maintained under hydroponic conditions until their heights and diameters attained the values specified by the Ministry of Agriculture and Supply, Ministerial Directive number 37-anexo-IX (Brazil, 2006) after which they were transplanted into perforated polyethylene vases $(30 \mathrm{~cm}$ high, $25 \mathrm{~cm}$ diameter) containing earth, corral manure and super simple fertilizer. These plants remained under observation and, at the present time, they have not presented any visible signs of stock-scion incompatibility and appear to be growing normally. The hydroponic system is technically viable for pear grafts production with reduction in the time required to produce pathogen-free seedlings in comparison with conventional methods.

\section{CONCLUSIONS}

Taiwan Naschi-C rootstocks was efficiently produced from pre-germinated seeds under hydroponic conditions, and about $70 \%$ of the seedlings reached transplanting and grafting stages at 37 and 77 days after transfer to nutrient solution, respectively.

Cleft grafting was the most appropriate for the propagation of pear grafts that were ready for commercialisation 35 days after grafting (or 112 days after initial transfer of rootstock seedlings to hydroponics).

Grafts produced with the cultivar Triunfo as scion exhibited faster growth in comparison with those produced with cultivars Cascatense or Tenra.

The hydroponic system is technically viable for pear grafts production with reduction in the time required to produce pathogen-free seedlings in comparison with conventional methods.

\section{ACKNOWLEDGEMENTS}

To Fundação de Amparo à Pesquisa do Estado de Minas Gerais - FAPEMIG and Conselho Nacional de Desenvolvimento Científico e Tecnológico - CNPq for financial support.

\section{CONFLITS OF INTEREST}

Information contained in this paper is protected in part by patent titled "Water plants: the production process of rootstocks and fruit forest and ornamental seedlings in hydroponics" with the IP protocol number 0802792-7 registered by the Universidade Federal de Lavras.

\section{REFERENCES}

1. BARBOSA, W.; CAMPO-DALL'ORTO, F.A.; OJIMA, M.; MARTINS, F.P.; CASTRO,J.L. L.; MARTINS, A.L.M.; SANTOS, R.R. Formação rápida de mudas vigorosas de pêra com porta-enxerto oriental. O Agronômico, v.47-50, p.28-31, 1998.

2. BARBOSA, W.; CAMPO-DALL'ORTO, F.A.; OJIMA, M.; MARTINS, F.P.; CASTRO, J.L. Desenvolvimento de cultivares e espécies de pereira enxertados em plantas de Taiwan Nashi-C na fase de formação de mudas. Bragantia, v.55, p.341345, 1996.

3. BARBOSA, W.; CAMPO-DALL'ORTO, F. A.; OJIMA, M.; MARTINS, F. P; MARTINS, A. L. M. Formação rápida de mudas vigorosas de pêra através de porta-enxerto oriental. Campinas: Instituto Agronômico, 1995. 12 p. (Datilografado).

4. BARBOSA, W; DALL'ORTO, F. A. C.; OJIMA, M.; NOVO, M. C. S. S.; BETTI, J. A.; MARTINS, F. P. Conservação e germinação de sementes e desenvolvimento de plantas da pereira porta-enxerto Taiwan Nashi-c. Scientia Agricola, v. 54, n. 3, p. 147-151, set./dez. 1997

5. BRASIL. Ministério da Agricultura, Pecuária e Abastecimento. Portaria № 37-annex-IX, 19 fevereiro de 2006. Normas e padrões específicos para a produção, comercialização e utilização de mudas de macieira (Malus spp.) e pereira (Pyrus spp.). Brasília., 2006. Disponível em: <http://www.apps.agr.br/upload/ax1 2802200736950800 port37-anexoix.pdf>. Acesso em: 10 abr. 2010.

6. COSTA, E.; LEAL, P.M. Avaliação de variedades de morangueiro em sistemas hidropônicos sob casa de vegetação. Revista Brasileira de Fruticultura, v.30, p. 425-430, 2008.

7. FAGAN, E.B.; GIEHL, R.F.H.; EISERMANN, A.C.; MEDEIROS, S.L.P.; BRACKMANN, A.; SIMON, J.; JASNIEWICZ, L.R.; SANTOS, O.S. Expansão de frutos de meloeiro hidropônico em dois intervalos entre irrigações. Revista Brasileira de Agrociência, v.12, p.287-293, 2006.

8. FAQUIN, V.; CHALFUN, N.N.J. Hidromudas: processo de produção de porta-enxerto de mudas frutíferas, florestais e ornamentais enxertadas em hidroponia (BRN.PI 0802792-7). Rio de Janeiro: INPI, 2008. Disponível em: <http:// www.patentesonline.com.br/hidromudas-processo-de-producao-de-porta-enxertos-e-mudas-frutiferas-florestais-e226848i.html>. Acesso em: 12 agosto 2010.

9. FERREIRA, D.F. Análise estatística por meio do SISVAR para Windows 4.0. In: REUNIÃO ANUAL DA REGIÃO BRASILEIRA DA SOCIEDADE INTERNACIONAL DE BIOMETRIA, 45, 2000. Proceedings da Reunião Anual, São Carlos: UFSCAR. Anais. 2000 p. 255-258.

10. GENÚNCIO, G.C.; MAJEROWICZ, N.; ZONTA, E.; SANTOS, A.M.; GRACIA, D.; AHMED, C.R.M.; SILVA, M.G. Crescimento e produtividade do tomateiro em cultivo hidropônico NFT em fungos da concentração iônica da solução nutritiva. Horticultura Brasileira, v.24, p.175-179, 2006.

11. HOLANDA NETO,. J.P.; HENRIQUES NETO, D.; CARDOSO, E.A.; PIRES, G.S.. Avaliação de métodos de enxertia em 
SOUZA, A.G. et al. Production of pears trees...

cajueiro. Revista Brasileira de Fruticultura, v.18, p.171-174, 1996.

12. LEDO, A.S.; FORTES, J.M. Avaliação de métodos de enxertia para a gravioleira em Viçosa - MG. Revista Brasileira de Fruticultura, v.13, p.63-66, 1991.

13. LEITE, G. B.; PETRI, L. J.; HAWERROTH, F. J. Problemática da Frutificação Efetiva na Cultura da Pereira. In: II Reunião Técnica da Cultura da Pereira, 2, 2008, Lages. Anais...Lages, SC. p.45-48.

14. MAIA, M.L.; AMARO, A.A.; GONÇALVES, J.S.; SOSA, S.A.M. Produção e mercado de pêra e pêssego no Brasil. Informações Econômicas, v. 26, p. 33-47, 1996.

15. MASSERON, A. Les porte-greffes pommier, poirier et nashi. Paris : Centre Technique Interprofessionnel des Fruits et Legumes (CTIFL), 1989.

16. MENDES, A.D.R. Produção e nutrição de mudas de pessegueiro em hidroponia. 2007. 46p. Dissertação (Mestrado em Fitotecnia) - Universidade Federal de Lavras, Lavras 2007.

17. NORA, I., SUGIURA, T. Estudo da entomofauna associada à cultura de pereiras japonesas (Housui, Kousui e Nijisseiki), em Santa Catarina, Brasil e técnicas de manejo. In: IV ENFRUTE (Encontro Nacional sobre Fruticultura de Clima Temperado), 1, 31-02 jul-ago. 2001, Fraiburgo, SC. Anais... Caçador: EPAGRI, 2001. p. 164.

18. REIS, J.M.R.; CHALFUN, N.N.J.; LIMA, L.C.O.; LIMA, L.C. Efeito do estiolamento e do ácido indolbutírico no enraizamento de estacas do porta-enxerto Pyrus calleryana Dcne. Ciência e Agrotecnologia, v. 24, p.931-938, 2000.

19. SIMONETTO, P.R.; GRELLMANN, E.O. Comportamento de cultivares de Pereira na região serrana do Rio Grande do Sul. Porto Alegre: FEPAGRO, (Boletim FEPAGRO, 9). 1999, 28p.

Recebido em 06/08/2010

Aceito em 16/02/2011 